the gas lifts a balanced bell at a rate controlled by a clock. A chain from the bell to a balance weight made as a sprocket chain passes over a sprocket wheel connected by a clutch to a clock-turned axle, the clutch acting in such a direction that the bell cannot rise faster than the clock permits, whilst it is always free to descend when weighted. This system of clock control of sampling lends itself readily to any agreed scheme of variation of the rate of sampling which may be considered equitable and in accordance with the variation of the rate of gas supply to the district during the hours of day and night. Should experience show that there is no loss of quality due to sampling and storage, the method would ensure one of the most important objects of the Gas Regulation Act being attained.

\title{
The Transmission of Excitation in Plants.
}

THE question of the mechanism of transmission of excitation in plants has been for some time under discussion in the columns of Nature. The most recent contribution to the discussion is a paper by Sir J. C. Bose, entitled "Physiological and Anatomical Investigations on Mimosa pudica," published on August $I$ in the Proceedings of the Royal Society (No. B 690, vol. 98).

The first section of the paper is devoted to the vexed question of the nature of the process of transmission. It has been suggested by Prof. Ricca that it is purely physical; a stimulating substance (hormone), produced at the seat of stimulation, is conveyed to the motile leaves by means of the transpiration-current in the vessels of the wood. Another suggestion, that of Mr. R. Snow, is to the effect that whilst Prof. Ricca's explanation may apply to transmission through relatively long distances in the stem, it does not apply to the petiole, where the excitation seems to travel from cell to cell. Sir J. C. Bose arrives at the conclusion that the process of transmission is the same in both stem and petiole; that it is not physical in either, but is wholly physiological, a wave of protoplasmic excitation, just as it is in the nerve of the animal.

The experimental evidence upon which his conclusion is based is both negative and positive. The author failed, after many attempts, to repeat the experiment upon which the transpiration-current theory depends, that is, to observe the transmission of excitation from one piece of stem to another connected with it by a glass tube containing water. Further, if the physical theory be true, it is obvious that the velocity of the transmission of excitation and that of the transpiration-current must be the same; but it was found that the former is far greater than the latter.

On the positive side, Sir J. C. Bose observed that transmission in Mimosa was affected experimentally in the manner well known in animal nerve. For example, in both the velocity of transmission is increased by rise of temperature and by desiccation. Again, on passing a moderately strong electric current ( 6 volts) through a length of the stem, the effect at " make" of the current was observed, by the fall of adjacent leaves in one direction, to be stimulation at the cathode; on breaking the current, stimulation was induced at the anode, evidenced by the fall of leaves in the opposite direction. It was further demonstrated that transmission is arrested by an electrotonic block; that is, excitation cannot travel along a tissue through which a constant electric current is being maintained. These results, obtained equally with stem and petiole, go to prove that excitation is transmitted in the plant in essentially the same manner as it is in the nerve of the animal.

The remaining sections of the paper deal mainly with anatomical details. The conclusion is reached that the phloem is the tissue that conducts excitation; not the sieve-tubes, but the elongated tubular cells of which the phloem mainly consists. Moreover, evidence is adduced that a strand of these tubular cells occurs also on the inner surface of each xylembundle, and this strand is termed the "internal phloem." The results of anatomical observation agree with those of physiological investigation by means of the electric probe. When the probe was inserted gradually into the petiole, maximum negative galvanometric deflexion was manifested when it penetrated the external phloem and again when it reached the internal phloem.

The paper concludes with a comparative study of the pulvinus, from which it appears that the more excitable the pulvinus the more deeply does the protoplasm of its contractile cells stain with safranin; it also reduces osmic acid, indicating the presence of a readily oxidisable substance, not a fat or a lipoid, which is probably concerned in developing the energy required for the active contraction of the organ.

\section{Earthquake Investigation in the United States.}

$\mathrm{A}^{\mathrm{S}}$ already mentioned in NATURE of April 25, p. $6 \mathrm{r}_{5}$, an act of the United States Congress was approved early this year, enacting " that the Coast and Geodetic Survey is hereby authorised to make investigations and reports in seismology, including such investigations as have been heretofore performed by the Weather Bureau." The reasons for the change and the work that it is hoped to accomplish are given in an excellent popular account (U.S. Coast and Geodetic Survey, Serial No. 304, price Io cents) by Mr. E. Lester Jones, the director of the Survey.

In I 899 , the Coast and Geodetic Survey developed a plan for the magnetic survey of the United States, and five observatories were established in places that proved to be admirably adapted for earthquake observations. Of these places-Porto Rico, Maryland, Arizona, south-east Alaska and Hawaiithree are in major earthquake zones and one near such a zone. As in other places, it was found that the magnetic instruments recorded certain kinds of earthquake waves, and they were supplemented by seismographs which have been in action for more than, twenty years. In I906, after the Californian earthquake, the Weather Bureau installed seismographs at Chicago, Washington and Northfield (Vt.) but, after a time, it was found that seismological investigation, and especially the instrumental part, did not fit in well with the work of the Weather Bureau, nor did the Coast and Geodetic Survey feel justified in attending to seismographs merely as an adjunct to its magnetic work. Accordingly, by agreement of the Secretaries of Agriculture and Commerce, Congress was asked to enact the legisla. tion referred to above.

In several ways, the ordinary work of the Coast and Geodetic Survey is adapted for earthquake investigations. The routine of operating magnetic NO. 2914 , VOL. I I 6] 
instruments, with the necessary attention to details which such precise instruments require, gives the observers the qualifications needed to get the best results from high-grade seismographs. The Survey maintains tidal stations at numerous points along the coast with continuous record by automatic gauges. Most important of all is the fact that the changes in the horizontal or vertical position of places in the central area of an earthquake can be determined only by precise triangulation and levelling. Such work by the Coast and Geodetic Survey has been in progress for three years in California, for it is understood that not only have changes occurring at the time of earthquakes to be considered, but also movements of large areas as a whole between earthquakes.

C. D.

\section{University and Educational Intelligence.}

A sUMmARY of important State Laws relating to education enacted in 1922 and 1923 has been published by the United States Bureau of Education in Bulletin 1925, No. 2. In the year 1923, laws were passed in twenty-two States prescribing instruction in the public schools in the constitution of the United States, the duties of citizenship, or "Americanism," which is defined (North Carolina) as including (a) respect for law and order, (b) character and ideals of the founders of the country, $(c)$ duties of citizenship, $(d)$ respect for the national anthem and the flag, $(e)$ a standard of good government, $(f)$ constitution of N. Carolina, $(g)$ constitution of the United States. In Florida, teachers and professors in State institutions were forbidden to teach atheism or agnosticism or to teach as true Darwinism or any other hypothesis that links man in blood relationship to any other form of life.

THE London County Council has again arranged numerous lectures for teachers during the winter, and a descriptive handbook has been prepared (The County Hall, Westminster Bridge, S.E.I.). The lectures scheme is now self-supporting, and last year's attendance approached I4,0oo. Any person engaged in teaching in London or Middlesex is eligible for admission at fees which average less than Is. a lecture ; out-county teachers are admitted at fees 50 per cent. higher. Among the lectures which will interest readers of NATURE are the following:- Special single lectures by Prof. J. Arthur Thomson on "Visualising in Nature Study," by Sir William Bragg on "Quartz," by Sir Sefton Brancker on "Aviation in the British Empire," Dr. A. S. Russell on " Radio-activity," Prof. Leonard E. Hill on " Sunlight and Open-Air Classes," and.by Mr. Richard Kearton on "Wild Life round London." Courses will be given by Prof. T. P. Nunn on science for the elementary school, by Dr. L. F. Bates on modern theories of magnetism, by Mr. J. W. Bispham on science-teaching in junior technical schools, by Prof. Cyril Burt on mental tests, and on experimental psychology and its bearing upon education. In mathematics there will be three courses dealing with the teaching of mathematics of different grades, while Prof. H. Levy is giving a course on the work of the mathematical laboratory. Geography is represented by courses on physical, regional and historical geography, on the teaching of local geography and on practical work in geography. These lectures are valuable in that they enable teachers to keep in touch with modern developments in their respective subjects.

THE City and Guilds of London Institute has issued as an addition to its report for 1924 (the forty-fifth annual report since the incorporation of the Institute) a report to the University of London by the University's Visitor, Sir Alfred Ewing, on the research, teaching, and equipment of the City and Guilds (Engineering) College. The Visitor found much to admire and very little to criticise. His observations relate to matters of such fundamental importance, and they are supported by lucid statements of principles so generally applicable, that they deserve attentive consideration by other engineering schools. Referring to the danger, to which all engineering schools are exposed, of overloading the course with a study of technological method and detail which takes up the time and attention that should be given to matters which are far more educative and, in the long run, of greater professional importance, Sir Alfred Ewing remarks that it " tends to become more acute where a school is divided into departments which may tempt a student to specialise prematurely, and where in each department there is a lavish equipment of large-scale engineering plant." $\mathrm{He}$ adds, however, that the course at the City and Guilds College, where the laboratories are extraordinarily spacious and splendidly equipped, is, on the whole, well balanced. Among the novel and interesting features of the laboratory work are testing machines of a new type designed by Prof. Dalby. A large section of the laboratory is not in use at present on account of the difficulty of paying rates on it. The technological examinations conducted by the Institute in Great Britain and Ireland were held at 297 centres, and the number of candidates examined was 8578 . In addition, $I_{32} 6$ candidates were examined in the Dominions Overseas (chiefly New Zealand) and India.

ThE League of Nations (Information Section) sends us a report on the "Instruction of Children and Youth in the Existence and Aims of the League" which is to be submitted to the Sixth Assembly opening in Geneva on September 7. The report shows that the League's propaganda has led to a vast amount of activity on the part of government departments, national associations of teachers, and other national and international organisations in the preparation of special pamphlets and magazine articles, the provision of special lectures and courses of instruction, the organisation of conferences, exhibitions, schemes for awarding special diplomas and badges, inter-scholar correspondence, exchange of students and international visits, and obtaining travelling facilities and collective passports. The Sixth Assembly is to consider, inter alia, a proposal that the League's Committee on Intellectual Cooperation should invite all professors and teachers to collaborate by preparing and distributing to all scholastic institutions literature instructing the young in the aims of the League. The effects of all these activities in different countries will depend to a great extent on the place already held in the national system of education by instruction in the duties of citizenship and practical exercises in those duties. Where, as in the United States, these are commonly recognised as an essential part of primary education, the attempt to establish a new loyalty to the ideals of the League may find a safe foundation of patriotism on which to work, but when this foundation is lacking the results may be unfortunate. In Great Britain, at any rate, it may well be asked whether the teaching of loyalty to that older league of nations known as the British Empire should not take precedence. "The internationalism that denies the worth of patriotic preference," says Wickham Steed in the preface to his reminiscences, " is as debilitating as is unqualified scepticism in regard to philosophical or religious belief.',

$$
\text { NO. } 29 \text { I } 4 \text {, VOL. I I6] }
$$

